\title{
EKONOMICZNA WARTOŚĆ DODANA JAKO MIERNIK ZARZĄDZANIA WARTOŚCIĄ PRZEDSIĘBIORSTWA - STUDIUM PRZYPADKU PKP CARGO SA
}

\author{
Marek Jóźwiak ${ }^{1}$ \\ Uniwersytet Technologiczno-Przyrodniczy im. Jana i Jędrzeja Śniadeckich w Bydgoszczy \\ Wydział Zarządzania
}

\begin{abstract}
Streszczenie: W artykule podjęto próbę weryfikacji ekonomicznej wartości dodanej jako miernika koncepcji zarządzania wartością przedsiębiorstwa. W części empirycznej analizie poddano spółkę PKP CARGO SA. Celem tej analizy było ustalenie wypracowanej wartości dla akcjonariuszy. Do dokonania oceny posłużył wskaźnik opracowany przez nowojorską firmę konsultingową Stern Stewart \& Co. W wyniku przeprowadzonego badania można stwierdzić, iż spółka PKP CARGO SA nie wypracowywała regularnie wartości dla akcjonariuszy. W analizowanym okresie tylko w jednym roku wskaźnik ekonomicznej wartości dodanej ukształtował się na poziomie dodatnim.
\end{abstract}

Słowa kluczowe: ekonomiczna wartość dodana, EVA, PKP CARGO SA, zarządzanie wartością przedsiębiorstwa

DOI: $10.17512 /$ znpcz.2020.2.03

\section{Wprowadzenie}

Wybór koncepcji, narzędzi do pomiaru wydajności i oceny przedsiębiorstwa wzbudza coraz większe zainteresowanie zarówno w środowiskach naukowych, jak i wśród praktyków. Jednym z podstawowych zadań każdego przedsiębiorstwa jest maksymalizacja korzyści dla właścicieli. W celu osiągnięcia wparcia podstawowego celu finansowego przedsiębiorstwa potrzebna jest długoterminowa maksymalizacja wartości rynkowej.

Zarządzanie wartością przedsiębiorstwa jest koncepcją, która uwzględnia powiększenie wartości dla akcjonariuszy. Jednym z mierników wykorzystywanych do pomiaru wartości kreowanej przez przedsiębiorstwo jest ekonomiczna wartość dodana. Ekonomiczna wartość dodana (ang. Economic Value Added - EVA) jest znakiem handlowym nowojorskiego przedsiębiorstwa konsultingowego Stern Stewart \& Co.

W niniejszym opracowaniu podjęto próbę weryfikacji ekonomicznej wartości dodanej jako miernika koncepcji zarządzania wartością przedsiębiorstwa. Cel empiryczny artykułu odnosi się do ustalenia wartości dla akcjonariuszy przez spółkę PKP CARGO SA, rozumianej jako ekonomiczna wartość dodana. Analizie poddano lata 2017-2019. Wskaźnik EVA został porównany do wyniku finansowego netto.

${ }^{1}$ Marek Jóźwiak, mgr, marek.jozwiak@utp.edu.pl, ORCID: 0000-0001-9291-7518 
Porównanie tych dwóch wartości w największym stopniu reprezentuje kontekst zainteresowań akcjonariuszy. Jako hipotezę przyjęto, iż spółka PKP SA nie wykazywała wartości dla akcjonariuszy.

\section{Zarządzanie wartością przedsiębiorstwa}

Zarządzanie wartością przedsiębiorstwa, inaczej z angielskiego Value Based Management (VBM), jest aktualnie jedną $\mathrm{z}$ dominujących strategii zarządzania współczesnym przedsiębiorstwem. Koncepcja ta umiejętnie odnosi się do potrzeb określenia konkretnych celów działania przedsiębiorstw. Dodatkowo sprzyja ona integracji celów właścicieli przedsiębiorstwa, jak i menedżerów (Jaki 2008, s. 142).

Pierwsze koncepcje zorientowanego na wartości podejścia do zarządzania przedsiębiorstwem były wymuszone zmianami w gospodarce. Teorie te zaczęły pojawiać się w Stanach Zjednoczonych w latach 80 . XX wieku. Za twórców koncepcji zarządzania wartością przedsiębiorstwa uważani są W.E. Fruhan (1979) i A. Rappaport (1986) (Berzakova, Bartosova, Kicova 2015, s. 318).

Przesłanką powstania koncepcji zarządzania wartością przedsiębiorstwa było pojawienie się negatywnych zdań właścicieli przedsiębiorstwa w związku z nieodpowiednim dbaniem przez zarząd o interesy przedsiębiorstwa (Dudycz 2005, s. 9-10).

Zarządzanie wartością przedsiębiorstwa to dziedzina, której dotyczą jedne z najszybciej rozwijających się teorii. Upływ czasu wpływa na poszerzenie się jej zakresu, ale pozwala również na wyodrębnienie się nowych kierunku rozwoju. Dodatkowo na rozwój tej koncepcji duży wpływ ma zjawisko globalizacji, postęp technologiczny czy rozwój informatyczny (Szczepankowski 2007, s. 20; Herman, Konopka 2015, s. 166).

Zarządzanie wartością przedsiębiorstwa można różnie interpretować, w zależności od spojrzenia na tę materię. $Z$ punktu widzenia pracowników firmy jest koncepcją, która pozwala na wdrożenie systemu wartości organizacji do działań przedsiębiorstwa oraz wpływa na kreowanie tradycji organizacyjnej. Dzięki temu przedsiębiorstwo może oferować usługi jak najwyższej jakości i zapewnić bardzo wysoki standard życia pracowników (Świątek-Brylska 2005, s. 227). Z innej strony zarządzanie wartością przedsiębiorstwa uwzględnia podjęcie decyzji o charakterze inwestycyjnym, organizacyjnym oraz finansowym. Podjęcie tych decyzji skutkuje podniesieniem wartości przedsiębiorstwa oraz wiąże się z powiększeniem wartości zainwestowanego kapitału, który ma wpływ na wzrost wartości rynkowej przedsiębiorstwa (Gorczyńska 2010, s. 92). Zarządzanie wartością przedsiębiorstwa jest połączeniem ze sobą najważniejszych elementów zarządzania strategicznego, zarządzania zasobami ludzkimi, zarządzania marketingowego oraz zarządzania finansami (Szczepankowski 2007, s. 23).

A. Rappaport, opisując tę teorię, uważał, że w najbliższych czasach będzie ona jedną z najczęściej wykorzystywanych koncepcji pomiaru i oceny wartości przedsiębiorstwa. Przesłanką przemawiającą za korzystaniem z koncepcji VBM jest zmniejszenie różnicy między wartością rynkową, którą przedsiębiorstwo jest w stanie osiągnąć, a wartością rynkową bieżącą (Rappaport 2000, s. 3). 
Zarządzanie wartością przedsiębiorstwa - jako jeden z elementów zarządzania strategicznego - polega na połączeniu ze sobą kilku głównych procesów zarządzania. Do tych procesów należy zaliczyć:

- Wyznaczenie celów - cele mają opierać się na czynnikach umożliwiających kształtowanie wartości przedsiębiorstwa. Właściwie sformułowane cele powinny przede wszystkim pomóc właścicielom przedsiębiorstw osiągnąć maksymalne korzyści finansowe z tytułu zainwestowanego kapitału, być odzwierciedleniem możliwości i aspiracji przedsiębiorstwa, być prosto sformułowane i nie być złożone. Ale przede wszystkim cele przedsiębiorstwa powinny być podporządkowane celowi głównemu, czyli maksymalizacji wartości dla właściciela.

- Sporządzenie strategii - ma na celu określenie sposobu realizacji, osiągnięcia określonych celów. Jeżeli przedsiębiorstwo we właściwy sposób określi swoją strategię, będzie mogło łatwiej budować przewagę konkurencyjną na rynku.

- Zdefiniowanie planu działania oraz przygotowanie budżetów - zadaniem jest stworzenie strategii, która pomoże podejmować przyszłe decyzje operacyjne. Dzięki zdefiniowaniu planu działania będzie możliwa kontrola zarządzania przedsiębiorstwem oraz jego pracownikami.

- Wprowadzenie pomiarów wyników oraz metod motywacyjnych jest pomocne w przekładaniu strategii na późniejsze działania operacyjne (Szczepankowski 2007, s. 25).

Zarządzanie wartością przedsiębiorstwa w obecnych czasach zyskuje na popularności. Związane jest to z ukierunkowaniem długoterminowych decyzji operacyjnych na zwiększenie majątku przedsiębiorstw. Dodatkowo zarządzanie wartością przedsiębiorstwa jest procesem, który rozpoczyna się od potencjalnego klienta, a kończy $\mathrm{u}$ inwestora.

\section{Czynniki tworzące wartość przedsiębiorstwa}

Jednymi z czynników, które wpływają na wartość przedsiębiorstwa, są:

- środki pieniężne,

- kapitał zaangażowany w aktywa przedsiębiorstwa,

- koszt kapitału (Szczepankowski 2007, s. 25).

Z kolei A. Rappaport do głównych czynników wpływających na wartość firmy zaliczył trzy:

- przepływy pieniężne z działalności operacyjnej,

- stopę kosztu kapitału,

- wysokość zadłużenia przedsiębiorstwa (Rappaport 2000, s. 78-79).

Czynniki wpływające na wartość przedsiębiorstwa można również podzielić ze względu na charakter finansowy i pozafinansowy. Do finansowych czynników może należeć m.in.: wysokość generowanej gotówki, kwoty, jaka została zainwestowana na poczet kapitału, czy koszty kapitału (Bieliński 2004, s. 175). Czynniki pozafinansowe można określić jako unikalne. Wynika to z ich charakteru. Są one, w przeciwieństwie do finansowych, trudne do zauważenia, niewykazywane w żaden sposób w księgach rachunkowych. Do czynników tych można zaliczyć m.in. wiedzę czy 
kapitał intelektualny. Skłądnikami kapitału ludzkiego są takie elementy jak: wiedza, umiejętności, innowacyjność i zdolności poszczególnych pracowników do efektywnej realizacji powierzonych im zadań. Dodatkowo do kapitału ludzkiego należy kulturę organizacyjną i filozofię. W obecnych czasach podstawowym czynnikiem wartości przedsiębiorstwa stał się kapitał intelektualny. Na Rysunku 1 przedstawiono czynniki, które wpływają na wartość przedsiębiorstwa (Paździor 2015, s. 28; Paździor, Twardowska 2017, s. 40).

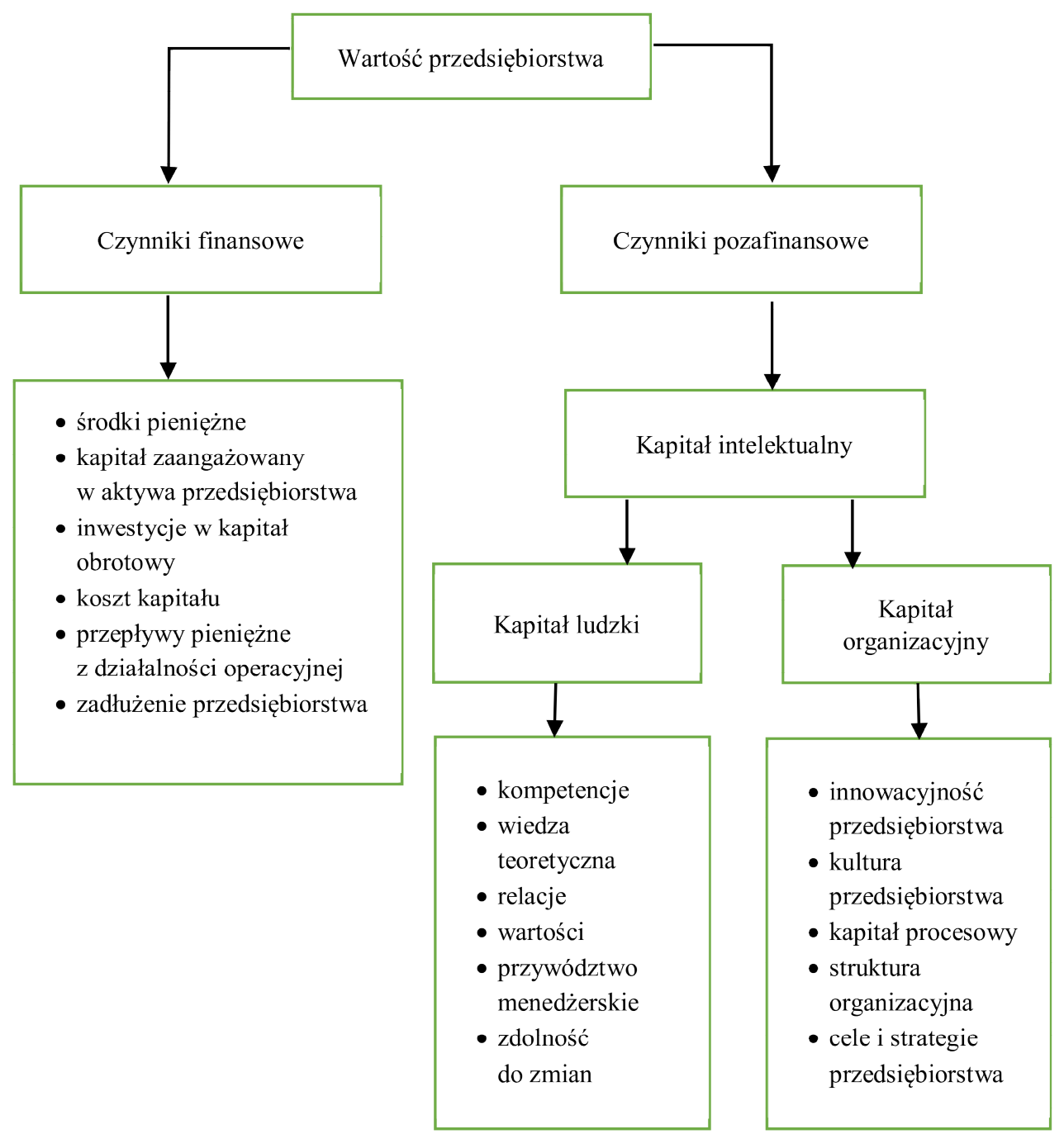

\section{Rysunek 1. Czynniki wpływające na wartość przedsiębiorstwa}

Źródło: Opracowanie własne na podstawie (Paździor 2015) 


\section{Metody wyceny wartości przedsiębiorstwa}

Wycena przedsiębiorstwa jest procesem, który polega na przeprowadzeniu pomiaru wartościowego przedsiębiorstwa i jego składników majątkowych. Dodatkowo ocenia się ekonomiczne efekty decyzji, które zostały podjęte przez zarządzających. Wycena przedsiębiorstwa pomaga odbiorcom ukazać efekty działań, które zostały powzięte w przeszłości i ułatwia wybór najlepszego wariantu w przyszłości (Steiger 2008, s. 3-4).

Wycenę przedsiębiorstwa można sklasyfikować na dwie grupy, mianowicie:

- Metody nierynkowe - jednym z podstawowych źródeł danych są sprawozdania finansowe.

- Metody rynkowe - informują o tym, że wiele informacji przydatnych do wyceny przedsiębiorstwa dostarcza rynek finansowy (Hill 2012, s. 25-33).

Spośród metod nierynkowych można wyróżnić trzy podstawowe grupy metod wyceny przedsiębiorstwa:

- Metody majątkowe, które można zaliczyć do tradycyjnych metod wyceny przedsiębiorstwa. Wartość przedsiębiorstwa ustalana jest na podstawie bilansu. W metodzie tej nie uwzględnia się przyszłego rozwoju, kondycji gospodarki, problemów wewnętrznych czy innych czynników, które nie są ujęte w sprawozdaniach finansowych (Szablewski, Tuzimka 2005, s. 144).

- Metody mieszane, których podstawą jest wartość mieszana. Wartość mieszana rozumiana jest jako średnia arytmetyczna (zwykła czy ważona) wartości majątkowej i dochodowej. Jest to wynikiem tego, iż wartość przedsiębiorstwa wpływa nie tylko na majątek, ale również na jego zdolność do generowania dochodu w przyszłych okresach czasu (Nowak 2010, s. 14; Machała 2014, s. 477-517).

- Metody dochodowe, których podstawą jest oszacowanie wartości sumy dochodów, jakie można pozyskać z eksploatacji przedsiębiorstwa w określonym czasie (Szablewski, Tuzimka 2005, s. 144).

Metody rynkowe służą do wyceny przedsiębiorstwa w praktyce rynkowej i są jedną z najczęściej wykorzystywanych metod. Jednym z głównych założeń, jakie trzeba przyjąć, aby stosować te metody, jest stwierdzenie, iż to rynek finansowy dostarcza najlepszych informacji na temat danego przedsiębiorstwa. Często w literaturze spotyka się inną nazwę tych metod - metody mnożnikowe (Dunal 2014, s. 63).

\section{EVA jako miernik wykorzystywany w koncepcji VBM}

Pierwsze wzmianki o zysku ekonomicznym pojawiły się w 1980 roku. Pisał o nim A. Marshall, który uważał, że po odjęciu od zysku odsetek od kapitału według stopy procentowej, która aktualnie obowiązuje, można nazwać go zyskiem z przedsięwzięcia lub z tytułu sprawowania zarządu. Dodatkowo zauważono, że firmy mogą generować zysk, jeśli zarabiają więcej niż ich własny koszt kapitałowy i zobowiązania (Nowicki 2016, s. 138; Petrescu, Apostol 2009, s. 1).

W kolejnych latach teoria o zyskach ekonomicznych była sukcesywnie rozwijana przez M. Millera oraz F. Modiglianiego. Obaj ekonomiści zgodnie zakładali, że wartość spółki oraz oczekiwana przez inwestorów stopa zwrotu określa pozom ryzyka 
oraz dochód ekonomiczny. W dalszych latach teoria była dopracowywana przez J.M. Sterna oraz B. Stewarta, aż do powstania miernika ekonomicznej wartości dodanej (Nowicki 2016, s. 138).

Ekonomiczna wartość dodana jest szeroko wykorzystywana w dzisiejszej praktyce gospodarczej. Służy ona do pomiaru wydajności przedsiębiorstwa i daje inwestorom możliwości analizy firmy. Koncepcja ekonomicznej wartości dodanej może być wykorzystywana w wielu kierunkach, takich jak motywowanie pracowników, system wynagradzania czy wycena przedsiębiorstwa. EVA może być wykorzystana przede wszystkim przy tworzeniu systemu motywowania menedżerów, którzy są odpowiedzialni w znaczny sposób za osiągnięcia przedsiębiorstwa (Nowicki 2016, s. 139; Singh i in. 2018, s. 270).

Ekonomiczna wartość dodana jest koncepcją, która obejmuje swoim zasięgiem nie tylko pomiar okresowych efektów, ale jest też podstawą do zarządzania finansami przedsiębiorstw. Może być traktowana jako jedna z miar wartości tworzonej przez przedsiębiorstwo. Na podstawie EVA oceniane są wyniki operacyjne z działalności firmy oraz z pracy zarządu z punktu widzenia zdolności do pomnażania zainwestowanego kapitału (Wypych 2014, s. 464).

Jednym z podstawowych zadań miernika EVA jest określenie wielkości zysku, który będzie pozostawać w przedsiębiorstwie po zmniejszeniu wyrażonego w kwocie średniego kosztu wszystkich kapitałów zainwestowanych w przedsiębiorstwie, tj. kosztu kapitału obcego oraz kosztu kapitału własnego. Kapitałem są środki, które udostępnia się przedsiębiorstwu za odpłatnością, i wyceniane są one według wartości rynkowej. Wynika z tego, iż do kapitałów zaliczyć można kapitał własny oraz kapitał obcy (zobowiązania obciążone oprocentowaniem). Każdy z inwestujących w kapitał własny oraz dawcy kapitału obcego spodziewają się zwrotu z inwestycji (Wypych 2012, s. 250-251).

Podstawę do obliczenia wskaźnika ekonomicznej wartości dodanej stanowi zysk operacyjny po opodatkowaniu (NOPAT), często określany w literaturze jako zysk operacyjny netto czy zysk operacyjny przed naliczaniem odsetek skorygowany o podatek dochodowy. Zysk operacyjny po opodatkowaniu wylicza się następująco:

$$
\text { NOPAT }=\text { EBIT } \times(1-t)
$$

gdzie:

EBIT - zysk operacyjny;

$\mathrm{t}$ - stopa opodatkowania zysku przedsiębiorstwa.

Zysk operacyjny jest często używany jako miara zdolności przedsiębiorstwa do generowania dochodów z zainwestowanego kapitału. Nie uwzględnia się źródeł pochodzenia tego kapitału oraz korzyści podatkowych związanych z poniesieniem kosztów finansowych (Wypych 2012, s. 251).

Po określeniu zysku operacyjnego po opodatkowaniu (NOPAT) ekonomiczną wartość dodaną (EVA) można wyliczyć dzięki następującemu wzorowi (Cwynar, Cwynar 2007, s. 32): 
gdzie:

IC - kapitał zainwestowany w aktywa przedsiębiorstwa (wartość księgowa

$\mathrm{z}$ bilansu);

WACC - średni ważony koszt kapitału.

Dzięki oszacowaniu wskaźnika ekonomicznej wartości dodanej można poznać odpowiedzi na pytanie, jak zarządza się powierzonym kapitałem. Dodatkowo można określić, czy przedsiębiorstwo generuje zyski przewyższające koszty zaangażowanego kapitału.

Każdy rodzaj kapitału jest związany z różnymi czynnikami ryzyka. Różny jest też oczekiwany zwrot $\mathrm{z}$ kapitału. Poprzez koszt kapitału rozumie się oczekiwaną przez inwestorów stopę zwrotu z zainwestowanego kapitału przy określonym poziomie ryzyka, jakie towarzyszy działalności przedsiębiorstwa. Do ustalenia WACC potrzebny jest koszt kapitału własnego według modelu CAPM. Wylicza się go za pomocą wzoru:

$$
\mathrm{R}=\mathrm{R}_{\mathrm{F}}+\beta\left(\mathrm{R}_{\mathrm{m}}-\mathrm{R}_{\mathrm{f}}\right)
$$

gdzie:

$\mathrm{R}_{\mathrm{F}}$ - stopa wolna od ryzyka;

$\mathrm{R}_{\mathrm{m}}$ - stopa zwrotu z rynku;

$\beta$ - współczynnik określający udział ryzyka danej akcji w ryzyku rynkowym.

Powyższy sposób określania kosztu kapitału oznacza, że zwrot, jakiego oczekują akcjonariusze, jest odpowiedni do ryzyka, które są w stanie ponieść. Dzięki zastosowaniu tego modelu określenia WACC uwzględnia się zależność pomiędzy ryzykiem a oczekiwaną rentownością z inwestycji.

Dodatkowo do wyliczenia WACC potrzebna jest wartość kosztu kapitału obcego. Ustala się go za pomocą wzoru:

$$
\mathrm{k}_{\mathrm{d}}=\mathrm{i}(1-\mathrm{T})
$$

gdzie:

$\mathrm{k}_{\mathrm{d}}$ - koszt kapitału obcego;

i - wartość odsetek.

Po wyliczeniu dwóch wartości można wyliczyć średni ważony koszt kapitału za pomocą wzoru:

$$
\mathrm{WACC}=\mathrm{R} \times \mathrm{U}_{\mathrm{R}}+\mathrm{k}_{\mathrm{d}} \times \mathrm{U}_{\mathrm{k}_{\mathrm{d}}}
$$

gdzie:

$\mathrm{U}_{\mathrm{R}}$ - udział kapitału własnego w pasywach przedsiębiorstwa;

$\mathrm{U}_{\mathrm{k}_{\mathrm{d}}}$ - udział kapitału obcego w pasywach. 


\section{Ekonomiczna wartość dodana - studium przypadku spółki PKP CARGO SA}

W niniejszym artykule poddano analizie jedną z największych spółek giełdowych, zaliczaną do grona największych operatorów logistycznych w Polsce oraz drugiego co do wielkości operatora kolejowych przewozów towarowych w Unii Europejskiej.

Opracowanie zostało przygotowane w oparciu o skonsolidowane sprawozdania finansowe $\mathrm{z}$ lat 2017-2019.

PKP CARGO SA powstało na mocy ustawy o komercjalizacji i restrukturyzacji przedsiębiorstwa państwowego Polskie Koleje Państwowe, uchwalonej 8 września 2000 r. Siedziba spółki mieści się w Warszawie. Głównymi zadaniami PKP CARGO SA według statutu jest: prowadzenie działalności związanej z transportem i gospodarką magazynową, prowadzenie działalności, która związana jest z handlem hurtowym oraz detalicznym, prowadzenie działalności oświatowej i technicznej, realizacja projektów budowlanych, prowadzenie działalności związanej z kupnem i sprze-dażą nieruchomości, prowadzenie działalności z zakresu administracji (Ustawa z dnia 8 września 2000 r. o komercjalizacji i restrukturyzacji przedsiębiorstwa państwowego „Polskie Koleje Państwowe”).

W Tabeli 1 przedstawiono strukturę akcjonariatu PKP CARGO SA.

Tabela 1. Struktura akcjonariatu PKP CARGO SA

\begin{tabular}{|c|c|}
\hline Najwięksi akcjonariusze & Udzial \\
\hline PKP SA & $33,01 \%$ \\
\hline Nationale-Nederlanden OFE & $15,25 \%$ \\
\hline AVIVA OFE & $5,22 \%$ \\
\hline Pozostali akcjonariusze & $46,51 \%$ \\
\hline
\end{tabular}

Źródło: Opracowanie własne na podstawie (https://www.pkpcargo.com/...)

W Tabeli 2 została przedstawiona wartość zysku operacyjnego (EBIT) spółki PKP CARGO SA w latach 2017-2019. Największy zysk spółka odnotowała w 2018 roku. W porównaniu z 2017 rokiem zysk operacyjny był wyższy o 79\%.

Tabela 2. Wartość zysku operacyjnego spółki PKP CARGO w latach 2017-2019

\begin{tabular}{|c|c|c|}
\hline Lata & EBIT & Zmiana \\
\hline 2017 & $155000000,00 \mathrm{zł}$ & - \\
\hline 2018 & $277600000,00 \mathrm{zł}$ & $79 \%$ \\
\hline 2019 & $143400000,00 \mathrm{zł}$ & $-48 \%$ \\
\hline
\end{tabular}

Źródło: Opracowanie własne na podstawie skonsolidowanych raportów grupy kapitałowej PKP CARGO za lata 2017-2019 (https://www.pkpcargo.com/media/712390/...; https://www.pkpcargo. com/media/821530/...; https://www.pkpcargo.com/media/956409/...)

W celu wyznaczenia wskaźnika EVA należy wyznaczyć zysk operacyjny po opodatkowaniu. W Tabeli 3 przedstawiono zysk operacyjny po opodatkowaniu (NOPAT). Wysokość podatku dochodowego w przypadku spółki PKP CARGO SA wynosiła 19\%. 
Tabela 3. Wartość zysku operacyjnego po opodatkowaniu spólki PKP CARGO w latach 2017-2019 oraz w pierwszym kwartale 2020 roku

\begin{tabular}{|c|c|c|c|}
\hline Lata & EBIT & $\begin{array}{c}\text { Podatek } \\
\text { dochodowy }\end{array}$ & NOPAT \\
\hline 2017 & $155000000,00 \mathrm{zł}$ & $19 \%$ & $125550000,00 \mathrm{z}$ \\
\hline 2018 & $277600000,00 \mathrm{zł}$ & $19 \%$ & $224856000,00 \mathrm{zł}$ \\
\hline 2019 & $143400000,00 \mathrm{zł}$ & $19 \%$ & $116154000,00 \mathrm{zł}$ \\
\hline
\end{tabular}

Źródło: Opracowanie własne na podstawie skonsolidowanych raportów grupy kapitałowej PKP CARGO za lata 2017-2019 (https://www.pkpcargo.com/media/712390/...; https:/www.pkpcargo. com/media/821530/...; https://www.pkpcargo.com/media/956409/...)

Średni ważony koszt kapitału (WACC) został ustalony na podstawie skonsolidowanego sprawozdania finansowego grupy kapitałowej PKP CARGO SA. W Tabeli 4 przedstawiono jego wartość procentową.

Tabela 4. Średni ważony koszt kapitału spólki PKP CARGO SA

\begin{tabular}{|c|c|}
\hline Lata & WACC \\
\hline 2017 & $5,71 \%$ \\
\hline 2018 & $6,03 \%$ \\
\hline 2019 & $5,33 \%$ \\
\hline
\end{tabular}

Źródło: Opracowanie własne na podstawie skonsolidowanych raportów grupy kapitałowej PKP CARGO za lata 2017-2019 (https://www.pkpcargo.com/media/712390/...; https://www.pkpcargo. com/media/821530/...; https://www.pkpcargo.com/media/956409/...)

W Tabeli 5 przedstawiono wartość ekonomicznej wartości dodanej. Wskaźnik ekonomicznej wartości dodanej tylko w jednym roku przyjął wartość dodatnią. $\mathrm{W}$ pozostałych analizowanych latach wartość tego wskaźnika była ujemna. Ujemna wartość wskaźnika oznacza, że stopa zwrotu z zainwestowanego kapitału była niższa od kosztu jego pozyskania. Dochód, który został uzyskany przez właścicieli, był również niższy od dochodu przez nich oczekiwanego.

Tabela 5. Ekonomiczna wartość dodana spółki PKP CARGO SA w latach 2017-2019 oraz pierwszym kwartale 2020 roku

\begin{tabular}{|c|c|c|}
\hline Lata & EVA & $\begin{array}{c}\text { Wyniki finansowe } \\
\text { PKP CARGO SA }\end{array}$ \\
\hline 2017 & $-64865823,80 \mathrm{zł}$ & $81673000 \mathrm{zł}$ \\
\hline 2018 & $14800950,00 \mathrm{zł}$ & $183900000 \mathrm{zł}$ \\
\hline 2019 & $-66307890,00 \mathrm{zł}$ & $36000000 \mathrm{zł}$ \\
\hline
\end{tabular}

Źródło: Opracowanie własne na podstawie skonsolidowanych raportów grupy kapitałowej PKP CARGO za lata 2017-2019 (https://www.pkpcargo.com/media/712390/...; https://www.pkpcargo. com/media/821530/...; https://www.pkpcargo.com/media/956409/...) 
W 2018 roku wartość wskaźnika ekonomicznej wartości dodanej ukształtowała się na poziomie 14800950,00 zł. Oznacza to, że zysk operacyjny przekroczył wymagania inwestorów. W pozostałych latach wartość wskaźnika ukształtowała się na poziomie ujemnym. Sugeruje to, że przedsiębiorstwo na przestrzeni badanych lat nie wygenerowało odpowiedniej wielkości przychodów, które pozwoliłyby na pokrycie wszystkich kosztów operacyjnych.

Pozytywnym zjawiskiem było wypracowanie przez spółkę PKP CARGO SA wyniku finansowego $\mathrm{w}$ latach 2017-2019 na dodatnim poziomie. Za pozytywne zjawisko należy także uznać, że spółka w latach 2017-2019 wypracowała zysk netto. We wszystkich analizowanych latach spółka PKP CARGO SA osiągała poziom wyniku finansowego wyższy od poziomu wskaźnika ekonomicznej wartości dodanej, co znajdowało odzwierciedlenie w informacjach zawartych w Tabeli 5.

\section{Podsumowanie}

Oprócz tradycyjnych metod, z pomocą których można dokonać oceny finansowej działalności przedsiębiorstwa (opartych na miernikach księgowych), coraz większe znaczenie zyskuje koncepcja zarządzania wartością przedsiębiorstwa, której główne założenie opiera się na kreowaniu wartości dla akcjonariuszy. Do oceny, czy przedsiębiorstwo tworzy wartość dla akcjonariuszy, wykorzystuje się wskaźnik ekonomicznej wartości dodanej.

Dzięki przeprowadzonemu badaniu spółki PKP CARGO SA udało się przyjąć postawioną wcześniej hipotezę. Spółka PKP CARGO SA nie tworzyła wartości dla akcjonariuszy w dwóch badanych okresach. Jedynie w 2018 roku wartość wskaźnika była na dodatnim poziomie. Należy pamiętać, że w interpretacji wskaźnika ekonomicznej wartości dodanej najważniejsza nie jest jej wartość aktualna, najbardziej pożądanym zjawiskiem jest połącznie wartości dodatniej z dalszą tendencją wzrostową.

Przyczyn takiego zjawiska można szukać choćby w tym, iż spółka PKP CARGO SA od początku 2016 roku operowała na niskiej marży i nie miała możliwości dostosowania kosztów do malejących tendencji rynku. Dodatkowo spółka poczyniła duże inwestycje, m.in. zakup nowych platform czy lokomotyw wielosystemowych. Ponadto za słabszy wynik finansowy w 2019 roku odpowiada ilość przewiezionego towaru - w grupie kruszyw i materiałów budowlanych było to $20,4 \mathrm{mln}$ ton $(-21,6 \%$ w porównaniu z rokiem 2018), w grupie metali i rud 9,3 mln ton $(-26,2 \%$ w porównaniu $\mathrm{z}$ rokiem 2018$)$ oraz w segmencie węgla $47,9 \mathrm{mln}$ ton $(-6,3 \% \mathrm{w}$ porównaniu $\mathrm{z}$ rokiem 2018).

W najbliższych latach spółka PKP CARGO SA nie będzie miała możliwości poprawy swoich wyników. Za przyczynę takiej sytuacji można uważać pandemię koronawirusa. Wybuch pandemii przyczynił się do spadku przewozów między innymi metali czy rud. Dodatkowo zamknięte były huty w Europie oraz wstrzymane dostawy złomu. 


\section{Literatura}

1. Berzakova V., Bartosova V., Kicova E. (2015), Modification of EVA in Value Based Management, „Procedia Economics and Finance”, Vol. 26.

2. Bieliński J. (2004), Zarządzanie wartościa przedsiębiorstwa a alokacja kapitatu, CeDeWu, Warszawa.

3. Cwynar A., Cwynar W. (2007), Kreowanie wartości spótki poprzez długoterminowe decyzje finansowe, Polska Akademia Rachunkowości, Warszawa-Rzeszów.

4. Dudycz T. (2005), Zarzadzanie wartościa przedsiębiorstwa, PWE, Warszawa.

5. Dunal P. (2014), Rynkowe metody wyceny przedsiębiorstw, „Folia Oeconomica”, nr 2(300).

6. Gorczyńska A. (2010), Problem pomiaru efektywności przedsiębiorstwa, „Zeszyty Naukowe Wyższej Szkoły Ekonomiczno-Społecznej w Ostrołęce”, nr 8.

7. Herman A., Konopka D. (2015), Teoria i praktyka zarzadzania wartościa ekonomiczna, „Zarządzanie i Finanse Journal of Management and Finance”, Vol. 13, No. 3/2/2015.

8. Hill R.A. (2012), Company Valuation and Takeover: Part II, Ventus Publishing ApS, London.

9. https://www.pkpcargo.com/media/712390/skonsolidowany-raport-roczny-grupy-kapita\%C5\%82owej-pkp-cargo-za-rok-2017.pdf (dostęp: 15.06.2020).

10. https://www.pkpcargo.com/media/821530/skonsolidowany-raport-roczny-grupy-pkp-cargoza-2018-rok.pdf (dostęp: 15.06.2020).

11. https://www.pkpcargo.com/media/956409/skonsolidowany-raport-roczny-za-2019-rok.pdf (dostęp: 15.06.2020)

12. https://www.pkpcargo.com/pl/relacje-inwestorskie/akcje/akcjonariat/ (dostęp: 13.07.2020).

13. Jaki A. (2008), Wycena i kształtowanie wartości przedsiębiorstwa, Wolters Kluwer, Kraków.

14. Machała R. (2014), Zarzadzanie finansami i wycena firmy, Oficyna Wydawnicza Unimex, Wrocław.

15. Nowak M. (2010), Wycena przedsiębiorstw, Centrum Edukacji Ekspert, Warszawa.

16. Nowicki D. (2016), Ekonomiczna wartość dodana w największych spółkach notowanych na giełdzie papierów wartościowych $w$ Warszawie, „Studia Ekonomiczne. Zeszyty Naukowe Uniwersytetu Ekonomicznego w Katowicach", Nr 282.

17. Paździor A. (2015), Zarządzanie wartościa współczesnego przedsiębiorstwa, Politechnika Lubelska, Lublin.

18. Paździor A., Twardowska S. (2017), Wpływ czynników niematerialnych na wartość przedsiębiorstwa na przykładzie spótek publicznych z indeksu WIG-Informatyka, „Zeszyty Naukowe Politechniki Częstochowskiej. Zarządzanie”, nr 26.

19. Petrescu S., Apostol C. (2009), Value Creation Analysis. Economic Value Added, „Theoretical and Applied Economics", Vol. 05(534)(supplement).

20. Rappaport A. (2000), Wartość dla akcjonariuszy. Poradnik menadżera i inwestora, WIG-Press, Warszawa.

21. Singh D., Gál Z., Huseynov R., Wojtaszek M. (2018), Determining the Performance Measurement of SME from Economic Value Added: Study on Hungary, Somogy County, „Problems of World Agriculture", Vol. 18(33), No. 2.

22. Steiger F. (2008), The Validity of Company Valuation Using Discounted Cash Flow Methods, Seminar Paper, European Business School, Cambridge.

23. Szablewski A., Tuzimka R. (2005), Wycena i zarzadzanie wartościa firmy, Poltext, Warszawa.

24. Szczepankowski P. (2007), Wycena i zarządzanie wartościa przedsiębiorstwa, Wydawnictwo Naukowe PWN, Warszawa.

25. Świątek-Brylska I. (2005), Kształtowanie relacji społecznych w organizacji w świetle zarzadzania przez wartość, [w:] Błaszczyk W. (red.), Metody organizacji i zarzadzania. Kształtowanie relacji organizacyjnych, Wydawnictwo Naukowe PWN, Warszawa.

26. Ustawa z dnia 8 września 2000 r. o komercjalizacji i restrukturyzacji przedsiębiorstwa państwowego „Polskie Koleje Państwowe” (Dz.U. 2000 nr 84 poz. 948). 
27. Wypych M. (2012), Ekonomiczna wartość dodana w przemysłowych spółkach giełdowych, „Przedsiębiorczość i Zarządzanie”, t. 13, z. 18.

28. Wypych M. (2014), Ekonomiczna wartość dodana w matych spółkach giełdowych, „Zeszyty Naukowe Uniwersytetu Szczecińskiego. Ekonomiczne Problemy Usług”, nr 111.

\title{
ECONOMIC VALUE ADDED AS A MEASURE OF VALUE-BASED MANAGEMENT - A CASE STUDY OF PKP CARGO SA
}

\begin{abstract}
The article attempts to verify the economic value added as a measure of the concept of enterprise value management. In the empirical part, the analysis of the company PKP CARGO SA was carried out, the purpose of which was to determine the value generated for shareholders. The assessment was developed by an indicator developed by the New York consulting company Stern Stewart \& Co. As a result of the study, it can be concluded that the company PKP CARGO SA did not regularly generate shareholder value. In the examined period, the indicator of economic value-added was positive only in one year.
\end{abstract}

Keywords: economic added value, EVA, PKP CARGO SA, Value-Based Management 